\title{
JONES v. ALFRED H. MAYER CO. \\ EXTENDED TO PRIVATE EDUCATION: \\ GONZALES v. FAIRFAX-BREWSTER SCHOOL, INC.
}

Brown $v$. Board of Education ${ }^{1}$ interpreted the fourteenth amendment as mandating the restructuring of southern public school systems to eliminate de jure racial segregation. Since that decision numerous alternative schemes have been devised to continue segregated education, but the courts, interpreting Brown broadly, have outlawed virtually all types of legislatively created segregation in public schools. ${ }^{2}$ As the failure of public school segregation became apparent, segregated private schools were created to avoid integration. ${ }^{3}$ These schools frequently received financial aid from government. But public education was construed broadly by the courts, and racial discrimination by such schools was held to be state action violating the equal protection clause of the fourteenth amendment. ${ }^{4}$ Until Gonzales v. Fairfax-Brewster School, Inc., ${ }^{5}$ however, segregated private schools operated without public assistance were not held illegal.

In this recent case, a District Court in the Eastern District of Virginia held that the maintenance of segregated private schools diminished the rights of blacks to make contracts in violation of section 1981 of title 42 , which guarantees, inter alia, that "all persons within the jurisdiction of the United States shall have the same right in every State . . to make and enforce contracts . . . as is enjoyed by white citizens . . . "6 The court, therefore, enjoined the defendants from discriminating according to race, and awarded compensatory damages to the plaintifts for "the embarrassment, humiliation and mental anguish" which they had suffered. ${ }^{7}$ This Comment will analyze that holding, criticize

1347 U.S. 483 (1954).

2 For a brief review of southern resistance to Brown, such as public school closing, "pupil assignment" laws, financial aid to private segregated schools, and "freedom of choice" plans, see Comment, Segregation Academies and State Action, 82 YALE L.J. 1436, 1436-40 (1973) [hereinafter cited as Segregation Academies]. For a collection of cases and commentary on various post-Brown issues, see T. EMERSoN, D. HABER \& N. Dorsen, 2 Political and Civil Rights in the Unrted States 1632-65 (3d ed. 1967).

${ }^{3}$ See Segregation Academies, supra note 2, at 1442 n.45.

4 See, e.g., Norwood v. Harrison, 413 U.S. 455 (1973) (state action found in lending textbooks to students at segregated private schools). See also Green v. Connally, $330 \mathrm{~F}$. Supp. 1150 (D.D.C.), aff'd mem. sub. nom. Coit v. Green, 404 U.S. 997 (1971) (segregated private schools not entitled to receive federal tax benefits because such tax benefits are not available for activities contrary to public policy).

5 Civil No. 494-72-A, consolidated with McCrary v. Runyon, Civil No. 495-72-A (E.D. Va., July 27, 1973).

6 Originally enacted as part of the Civil Rights Act of $1866, \mathrm{ch} .31, \S 1,14$ Stat. 27 , reenacted, Enforcement Act of 1870, ch. 114, $\$ 18,16$ Stat. 140, 144 (now 42 U.S.C. §§ $1981,1982(1970))$.

${ }^{7}$ Civil No. $494-72-\mathrm{A}$, at $9-10$. 
the basis on which it was reached, and offer an alternative rationale by which the Gonzales result might be justified.

\section{Gonzales v. Fairfax-Brewster School, Inc.}

In Gonzales the plaintiffs were two children (and their parents) who were denied admission to two all-white nonprofit private schools. ${ }^{8}$ One of the children was also denied admission to a day camp operated by one of the schools. ${ }^{9}$ District Judge Bryan concluded that the denials were solely "because plaintiffs were black."10 Although this conclusion was contested at trial by the defendant schools and personnel, the issues of law were clarified by the intervening codefendant, the Southern Independent School Association, which stipulated that its member schools discriminated according to race. ${ }^{11}$

The plaintiffs' attack under section 1981 took the following form. As a result of defendants' discriminatory practices, white people could contract with the defendant schools for the education of their children, but blacks could not. Thus, a black person's right to make contracts was less than that of a white person. Defendants' practices were therefore in violation of section 1981.

The district court's acceptance of this conclusion relied heavily on the Supreme Court's decision in Jones v. Alfred H. Mayer Co. ${ }^{12}$ which construed a companion provision, section $1982,{ }^{13}$ to prohibit not only discriminatory state action but also discrimination by individuals. Because section 1981 was closely related in origin to section $1982,{ }^{14}$ the Court reasoned, it should also be construed to apply to private action. ${ }^{15}$ On finding private action which diminished the plaintiffs' right to make contracts, the court granted the relief which plaintiffs sought. Although damages were awarded against only the two originally named schools, the injunction prohibited racial discrimination on the part of these schools and the intervenor, which represented 396 segregated schools. ${ }^{16}$

In reaching this holding, Judge Bryan was unmoved by the intervenor's assertion of a constitutional right on the part of

${ }^{8}$ One of the defendant schools was founded in 1955 , the other in $1958.1 d$. at 1 .

${ }^{9}$ Id. at 3 .

${ }^{10}$ Id. at 5 .

${ }_{11}$ The intervenor claimed to represent "nonprofit, private white schools in seven states." Id. at 6. The Southern Independent Schools Association is said to represent "396 academies with a combined enrollment of 176,000." Segregation Academies, supra note 2, at 1448, citing Southern Independent Schools Association Represent 176,000, THE CITIZEN, Dec.

1971 , at $17,18,29$.

i2 392 U.S. 409 (1968).

1342 U.S.C. \$ 1982 (1970).

${ }^{14}$ See text accompanying note 31 infra.

15 Civil No. 494-72-A at 7.

${ }^{16}$ See text accompanying note 11 supra. 
parents to send their children to segregated schools. Such schools were said to be "protected political expression of the associational and speech freedoms of the related parents under the first amendment." 17 The intervenor claimed that the exercise of parental prerogatives in this case was rationally related to education and therefore legitimate because there was "substantial scientific evidence"18 showing that segregated education is advantageous to students. Judge Bryan held that this claim was "irrelevant to the issue in these actions" as it "embodie[d] a concept rejected in Brown $v$. Board of Education." 19

\section{Jones and Its Section 1981 Progeny}

Jones v. Alfred H. Mayer Co. was a section 1982 action brought by a black person whose offer to buy a home was refused by a white seller. Section 1982 provides that "[a]ll citizens of the United States shall have the same right, in every State and Territory, as is enjoyed by white citizens thereof to inherit, purchase, lease, sell, hold and convey real and personal property." 20 The Supreme Court held that "Congress meant exactly what it said" 21 in section 1982, which "[o]n its face . . . appears to prohibit all discrimination against Negroes in the sale or rental of property-discrimination by private owners as well as discrimination by public authorities." ${ }^{22}$ This literal interpretation was based on the Court's belief that if a white seller can refuse to sell a home to a black person, solely because of the color of the latter's skin, that black man does not have the same right to purchase property as a white man.

Having found that Congress intended to remove all restrictions on the right to purchase land, personal as well as governmental, Justice Stewart, writing for the majority in Jones, questioned the constitutionality of the Congress' passing such an act. The Court found the power for such legislation in the enforcement clause of the thirteenth amendment. ${ }^{23}$ While the fourteenth amendment prohibits only state action, ${ }^{24}$ the thirteenth

17 Memorandum of Intervenor-Defendant at 18, McCrary v. Runyon, Civil No. 495-72-A (E.D. Va., July 27, 1973).

${ }^{18}$ Civil No. $494-72-A$ at 8.

19 Id.

2042 U.S.C. \& 1982 (1970).

21392 U.S. at 422.

22 Id. at 421 .

23 U.S. CONST. amend. XIII provides:

Section 1. Neither slavery nor involuntary servitude .... shall exist within the United States, or any place subject to their jurisdiction.

Section 2. Congress shall have power to enforce this article by appropriate legislation.

24 See, e.g., Moose Lodge No. 107 v. Irvis, 407 U.S. 163 (1972); Reitman v. Mulkey, 387 U.S. 369 (1967); Burton v. Wilmington Parking Authority, 365 U.S. 715 (1961); Civil Rights Cases, 109 U.S. 3, 11 (1883). U.S. Const. amend. XIV, \& 1 provides, in relevant part: 
amendment's prohibition of slavery had been construed, as early as 1880 , to include all the "badges and incidents thereof." the act was passed pursuant to the enforcement clause of the thirteenth amendment is supported by the chronological history of the act, for today's section 1982 was originally passed as part of the Civil Rights Act of 1866, two years before the fourteenth amendment was approved. ${ }^{26}$

The Constitutional issue aside, however, Justice Stewart's reading of the statute in Jones is rather tenuous. To call the capacity to buy a particular house a "right" is an expansive interpretation of the word. It is more likely that Congress was correcting legal disabilities of newly freed slaves, whose right to purchase or own property was often limited by law, even if they found a willing seller. ${ }^{27}$ Furthermore, it is simply not clear that Congress intended section 1982 (and section 1981) to apply to private acts of discrimination. Justice Harlan, dissenting in Jones, ${ }^{28}$ provided a convincing counterreading of the legislative history. His interpretation certainly seems more in line with the racial attitudes and social thought of the period.$^{29}$ Commentators have disagreed about whose legislative history is correct, ${ }^{30}$ but the issue will be hereafter considered closed by the Supreme Court's unequivocal holding.

What are the implications of Jones for section 1981 and its "right to make contracts"? If securing the right to purchase

No State shall make or enforce any law which shall abridge the privileges or immunities of citizens of the United States; nor shall any State deprive any person of life, liberty, or property, without due process of law; nor deny to any person within its jurisiction equal protection of the laws.

${ }_{25}$ Civil Rights Cases, 109 U.S. 3, 20 (1883).

${ }^{26}$ See note 6 supra. The reenactment of the statute in 1870 does not indicate any change in the constitutional support tor the statute.

For a history and analysis of the Black Codes passed by the southern states just after the Civil War, see T. WILSON, THE BLACK CoDEs OF THE South 61-117. These included disabilities on blacks in ownership of personal and real property, in making employment contracts and in various other areas.

${ }_{28} 392$ U.S. at 453-76.

${ }^{29} \mathrm{Id}$. at 473-74 (Harlan, J., dissenting):

Many of the legislators who took part in the congressional debates inevitably must have shared the individualistic ethic of their time, which emphasized personal freedom and embodied a distaste for governmental interference which was soon to culminate in the era of laissez-faire. It seems to me that most of these men would have regarded it as a great intrusion on individual liberty for the Government to take from a man the power to refuse for personal reasons to enter into a purely private transaction involving the disposition of property, albeit those personal reasons might reflect racial bias. It should be remembered that racial prejudice was not uncommon in 1866, even outside the south. (footnotes omitted)

${ }^{30}$ For a favorable view of the majority's legislative history, see Kohl, The Civil Rights Act of 1866, Its Hour Come Round at Last: Jones v. Alfred H. Majer Co., 55 VA. L. Rev. 272 (1969). For an opposing view, see Casper, Jones v. Mayer: Clio, Bemused and Confused Muse, 1968 Sup. CT. REv. 89. It has also been suggested that though the framers of the thirteenth amendment did not intend it to be as broad as Jones makes it, a broader interpretation of "slavery" is an acceptable way of expanding the amendment's protection. Comment, The "New" Thirteenth Amendment: A Preliminary Analysis, 82 HARv. L. REv. 1294 (1969). 
property means forcing an owner who has put his property on the market to sell to a buyer he finds personally objectionable because of race, it follows that enforcing the right to make contracts could entail forcing a similarly unwilling party to contract. The sale of land is itself one type of contractual transaction. Moreover, both section 1981 and section 1982 were originally included in section 1 of the Civil Rights Act of $1866 ;^{31}$ this common beginning supports parallel constructions.

In numerous cases courts have adopted the Court's reasoning in Jones in their interpretations of section 1981. In private employment discrimination cases, the relationship between the sections has been recognized, and black plaintiffs were found to have stated causes of action under section 1981 for impairment of their right to contract. ${ }^{32}$ In Sims $v$. Order of United Commercial Travelers of America, ${ }^{33}$ a district court held that the defendant, which claimed to be a fraternal organization, was primarily an insurance company offering to contract with the white public only, in violation of section $1981 .^{34}$ Discrimination against blacks by a privately owned recreational facility was challenged in Scott v. Young. ${ }^{35}$ Admission was found to be a contract; refusal of admission to blacks, a violation of section $1981 .^{36}$ In Grier $v$. Specialized Skills, Inc., ${ }^{37}$ the refusal of a barber school to admit blacks as students or as discount customers on which students could practice was found to be a violation of section 1981. Thus,

${ }^{31}$ See note 6 supra.

${ }^{32}$ Payne v. Ford Motor Co., 461 F.2d 1107 (8th Cir. 1972); Brady v. Bristol-Myers, Inc., 459 F.2d 621 (8th Cir. 1972); Young v. ITT, 438 F.2d 757 (3d Cir. 1971); Boudreaux v. Baton Rouge Marine Contracting Co., 437 F.2d 1011 (5th Cir. 1971); Sanders v. Dobbs Houses, Inc., 431 F.2d 1097 (5th Cir. 1970), cert. denied, 401 U.S. 948 (1971); Waters v. Wisconsin Steel Works of Int'l Harvester Co., 427 F.2d 476 (7th Cir.), cert. denied, 400 U.S. 911 (1970); Tramble v. Converters Ink Co., 343 F. Supp. 1350 (N.D. III. 1972); Page v. Curtiss-Wright Corp., 332 F. Supp. 1060 (D.N.J. 1971); Tolbert v. Daniel Constr. Co., 332 F. Supp. 772 (D.S.C. 1971); Rice v. Chrysler Corp., 327 F. Supp. 80 (E.D. Mich. 1971); Washington v. Baugh Constr. Co., 313 F. Supp. 598 (W.D. Wash. 1969); Central Contractors Ass'n v. Local 46, IBEW, 312 F. Supp. 1388 (W.D. Wash. 1969); Clark v. American Marine Corp., 304 F. Supp. 603 (E.D. La. 1969); United States v. Medical Soc'y of S.C., 298 F. Supp. 145 (D.S.C. 1969) (dictum); Dobbins v. Local 212 IBEW, 292 F. Supp. 413 (S.D. Ohio 1968) (dictum), aff'd sub nom. United States v. Local 212, IBEW, 472 F.2d 634 (6th Cir. 1973). Contra, Smith v. North Am. Rockwell Corp., 50 F.R.D. 515 (N.D. Okla. 1970); Culpepper v. Reynolds Metals Co., 296 F. Supp. 1232 (N.D. Ga. 1969), rev'd on other grounds, 421 F.2d 888 (5th Cir. 1970); Colbert v. H-K Corp., 295 F. Supp. 1091 (N.D. Ga. 1968), vacated on other grounds, 444 F.2d 1381 (5th Cir. 1971).

${ }^{33} 343$ F. Supp. 112 (D. Mass. 1972).

${ }^{34}$ Id. The facts of Sims indicate that there were members of the organization who did not take advantage of the insurance program, so the club argument was not without factual support. Still, the court held that United Commercial Travelers was merely calling " "private' that which is truly "public," $i d$. at 114 , and so could not be immune from $\$ \$$ 1981 and 1982.

${ }_{35}^{35} 421$ F.2d 143 (4th Cir.), cert. denied, 398 U.S. 929 (1970).

${ }^{36}$ Id. at 145 (dictum). The court also found a violation of the Civil Rights Act of 1964, tit. II, $\S 201(\mathrm{a}), 42$ U.S.C. $\S 2000$ a (1970), making the section 1981 analysis unnecessary.

${ }^{37} 326$ F. Supp. 856 (W.D.N.C. 1971) (dictum). The presence of state licensing in the case made the fones extension of section 1981 to private action unnecessary to the holding. 
when faced with the section 1981 argument, the court in Gonzales had many precedents which pointed in the direction of finding private discrimination in contractual transactions illegal.

\section{Section 1981 and Freedom of Association}

There were at the same time, however, some indications that should have cautioned the Gonzales court against unqualified extension of the Jones rationale in section 1981 cases such as the one before it. In Moose Lodge v. Irvis, ${ }^{38}$ for instance, the Court found the lodge's discrimination against blacks immune from attack under section 1983. The Court's holding was based on its failure to find state action and not on a recognition of any affirmative right of defendant as a private fraternal organization. But even Justices Douglas and Marshall, who dissented from the holding because they found state action in the lodge's liquor license and in other state regulations, believed that the government was "constitutionally prohibited from interfering with [truly] private clubs or groups." 39 It is difficult to imagine that simply by framing his complaint under section 1981, Irvis could have changed the Court's result. Yet the purchase of a drink at a bar, even a private one, and certainly the payment of membership dues, can be considered contractual agreements if the term "contract" is construed at all broadly. If the Jones rationale were to be applied woodenly to all section 1981 cases in which there is both discrimination according to race and something that can be characterized as a contractual relationship, then Moose Lodge would soon be brushed aside. Only by abandoning this simplistic approach and by taking associational rights into account in determining the reach of section 1981, can one imagine a world in which both Jones and the Moose Lodge result can live side by side.

\section{A. Associational Rights in the Context of Private Education}

Freedom of association has been broadly defined as "the constitutional right of every person to close his home or club to any person or to choose his social intimates and business partners solely on the basis of personal prejudices including race." 40 This freedom would seem to figure much more strongly in cases such as Gonzales than in Jones and many of the cases decided under section 1981. For private education has been considered a particularly important manifestation of these rights, although in

\footnotetext{
${ }^{38} 407$ U.S. 163 (1972).

${ }^{39} I d$ at $179-80$.

40 Bell v. Maryland, 378 U.S. 226, 313 (1964) (Goldberg, J., concurring).
} 
the context of education they have often been cast as "privacy" or "parental" rights.

In Griswold v. Connecticut, ${ }^{41}$ the first case to adopt the right of privacy argument, Justice Douglas included the parents' freedom to choose an educational institution for their children among those rights encompassed in the phrase "right of privacy." Relying on a case decided approximately forty years earlier, Justice Douglas wrote: "The right to educate a child in the school of the parents' choice-whether public or private or parochial-is . . . not mentioned [in the Bill of Rights]. . . . Yet the First Amendment has been construed to include [that right]." 42

In Pierce v. Society of Sisters, ${ }^{43}$ the case Justice Douglas cited in Griswold, the Supreme Court, in a decision protecting two schools-one religious, the other military-held that Oregon could not constitutionally force all children in the state to attend public schools, although it could "reasonably" regulate alternative private schools and require "that nothing be taught which is manifestly inimical to the public welfare." 44 Pierce was reaffirmed by the Court in 1971 in Wisconsin $v$. Yoder. ${ }^{45}$ In that case, Wisconsin's compulsory education law (until age sixteen) was found invalid as applied to Amish children since the state's "interest in universal education, however highly we rank it, is not totally free from a balancing process when it impinges on other fundamental rights and interests, such as . .. the traditional interest of parents in the religious upbringing of their children ...."46

The strength of associational or privacy rights in the context of private schools which practice racial discrimination is brought into question by the recent Norwood $v$. Harrison decision. ${ }^{47}$ That case presented the issue of the constitutionality of the state's providing textbooks to students attending segregated private schools. In vacating the decision of a three-judge court upholding the statute under which the textbooks were provided, the Court found that "[i]nvidious private discrimination . . . has

41381 U.S. 479 (1965).

42 Id. at 482 .

43268 U.S. 510 (1925).

44 Id. at 534. This textual description of the holding in Pierce parallels that of Justice White in his concurring opinion in Wisconsin v. Yoder, 406 U.S. 205, 239 (1972), approved by a majority of the Court in Norwood v. Harrison, 413 U.S. 455, 461-62 (1973).

45406 U.S. 205 (1972).

${ }^{46} I d$. at 214.

The Court in Yoder clearly saw that the rights of the parents in that case to educate their children as they wished were inextricably bound up with the parents' claims to free exercise of religion. But it did not suggest that the basis of freedom of choice in education was confined to religious association.

47413 U.S. 455 (1973). 
never been accorded affirmative constitutional protections," least not of the sort that would require that segregated private schools "share with public schools in state largesse." 49 At the same time, however, Norwood's discussion of Pierce and Yoder did not indicate that those cases offered no protection of segregated schools. For our present purposes, it is not necessary to show that private education provides circumstances under which, as the Court in Norwood put it, "the Constitution may compel toleration of private discrimination ...."50 All we need conclude is that the constitutional rights recognized in Griswold, Pierce and Yoder are strong enough to influence a court's construction of the intended reach of statutory provisions such as section 1981 in the context of private school segregation.

\section{B. Construing Section 1981 in Light of Associational Rights}

In view of the demonstrated solicitude towards private education as an expression of the freedom of association or the right of privacy, the application of section 1981 in Gonzales is questionable. Yet section 1981 itself advances an important constitutional interest, and surely any attempt to alter its construction in Gonzales by excluding it entirely from the field of private contractual arrangements would significantly impair that interest as well as ignore the widely recognized precedential value of Jones in section 1981 cases. A balancing of constitutional interests is necessary to produce a proper construction of section 1981 .

Our discussion to this point suggests where the balance might be struck without seriously impairing either right. The right to contract protected in section 1981 should be limited to contracts found in secondary, as contrasted with primary, relationships." ${ }^{51}$ The former are "basically relationships between friends," 52 characterized by " intimate association." "53 Secondary relationships, by contrast, are "impersonal, highly formalized relations between people"; 54 for example, the relations "between buyer and seller, borrower and lender, consumer and manufacturer, and so on ...."55 Under this approach, discrimination would be allowed in primary relationships for any reason whatever, ${ }^{56}$ including racial bias, while in secondary contractual

48 Id. at 470 .

49 Id. at 462 .

${ }^{50} \mathrm{Id}$. at 463 (emphasis added).

51 Sengstock \& Sengstock, Discrinination: A Constitutional Dilemma, 9 WM. \& MARY L. REv. 59, 117 (1967).

52 Id.

${ }^{53}$ Id.

${ }^{54} I d$.

55 Id. $117-18$.

${ }^{36}$ Id. $116-20$. 
relationships discrimination would be disallowed when directed at an entire group without reasonable ground. ${ }^{57}$

Such an analysis explains the difference in outcome in Jones and Moose Lodge. The relationship between the buyer and seller of a home is a formal one, in which the only relevant consideration should be the buyer's ability to pay for the house. By contrast, a lodge or social club is founded upon the fraternal ties of its members.

This distinction between primary and secondary relationships is often more difficult to draw. Gonzales itself may be a difficult case. The private school is offering to the public a commodity-education-and perhaps anyone who can afford to pay tuition should be allowed to enroll his child. But the private school involves intimate relationships as well: the teacher-student relationship, the student-student relationship, and, most significantly, the parent-child relationship. The parents' right to control the upbringing of their children is among the most intimate of relationships and is, in fact, constitutionally protected, as explained above. ${ }^{58}$

Under this analysis, if the private school is a secondary relationship, then the court's decision in Gonzales-that racial discrimination in the private school is a violation of the right to contract protected by section 1981-was appropriate. However, if the parental right to choose an educational forum raises the private school to a primary relationship, then the Gonzales court's basing its decision on section 1981 was incorrect and, if the court's decision is to be affirmed on appeal, another ground must be found for affirmance.

\section{An Alternative: Private Education as State Action Under the Fourteenth Amendment}

Though the concept of "state action" is also difficult to define satisfactorily, it provides the most workable standard for determining when discrimination is constitutionally prohibited. Under such a standard, when state action is not involved, discrimination would be permissible within the framework of the fourteenth amendment. ${ }^{59}$ The resulting decisions would be con-

${ }^{37}$ Id. $120-24$.

${ }^{58}$ See text accompanying notes 41-46 supra.

s9 Some discrimination, although permissible under the fourteenth amendment, is illegal nonetheless, having been outlawed by the states. State legislatures are not bound by the limitations on Congress' power to enforce the thirteenth and fourteenth amendments. Some states have passed legislation outlawing discrimination on racial grounds by all schools, public and private, which accept applications "from the public generally" and which are not in their nature "distinctly private." E.g., MAss. ANN. Laws ch. 151C, \$\$ 1-5 (1973 Supp.). Other states have included discrimination by schools under the prohibition of discrimination by places of public accommodation. E.g., PA. Srar. ANN. tit. 43, \$§ 953, 954 (l) (Supp. 1973). See also MODEL ANTI-Discrimination ACT $\S 502$, which provides: 
sistent and relatively easy to determine. In the context of Gonzales, the fourteenth amendment's prohibition of discrimination could be interpreted to prohibit private school segregation.

Various methods of delineating state action have been proposed. Professor Henkin has proposed that a concept of "state responsibility" be read into the state action doctrine. Under such an analysis, a state government is held responsible not only for its affirmative actions but also for "what it could prevent, and should prevent, and fails to prevent," 60 or for "discrimination which it encourages or sanctions." ${ }^{1}$ This approach would limit the state's responsibility to situations where it could act; that is, there would be unconstitutional state action where inaction itself would infringe upon constitutionally protected privacy and associational interests. In effect requiring a state to outlaw any discrimination it could constitutionally prohibit, this plan seems simple and workable. A difficult and important question that would have to be answered in the application of this approach, however, is how far the state could constitutionally move to prevent discrimination in private areas without intruding impermissibly on private associational rights. As in our construction of section 1981, the advancement of the goal of a desegregated society would have to be balanced against the protection of personal privacy, the right to choose one's friends and associates. If we were to strike the balance, as we did in the case of section 1981, by resorting to a distinction between primary and secondary relationships, the applicability of the fourteenth amendment in Gonzales and cases like it would be open to serious question.

The necessity of balancing could be avoided by adopting the "public function" approach to state action in cases such as Gonzales. Such an approach has been recognized in the courts. In Smith $v$. Allwright, ${ }^{62}$ the Supreme Court held that exclusion of blacks from party primary elections by action of the party's convention violated the fifteenth amendment's guarantee of the right to vote, even though that amendment prohibited only state action. ${ }^{63}$ The Court found that "state delegation to a party of the

It is a discriminatory practice for an educational institution

(1) to exclude, expel, limit, or otherwise descriminate against an individual seeking admission as a student or an individual enrolled as a student in the terms, conditions, and privileges of the institution, because of race, color, religion, or national origin . . . .

1966 Handbook of the National Conference of Commissioners on Uniform State LAws 193, 202.

${ }^{60}$ Henkin, Shelley v. Kraemer: Notes for a Revised Opinion, 110 U. PA. L. REv. 473, 483-85 (1967).

61 Id. 485 .

62321 U.S. 649 (1944).

${ }^{63}$ U.S. ConST, amend. XV, $\S 1$ provides: "The right of citizens of the United States to vote shall not be denied or abridged by the United States or by any State on account of race, color, or previous condition of servitude." (Emphasis added.) 
power to fix the qualifications of primary elections is delegation of a state function that may make the party's action the action of the State."64

Marsh v. Alabama, ${ }^{65}$ another case adopting the public function approach, involved a company town's prohibition of activity protected by the first and fourteenth amendments. The company's action was deemed to be state action:

The more an owner, for his advantage, opens up his property for use by the public in general, the more do his rights become circumscribed by the . . . constitutional rights of those who use it. . . . Since [privately owned bridges, ferries, turnpikes and railroads] are built and operated primarily to benefit the public and since their operation is essentially a public function, it is subject to state regulation. ${ }^{66}$

Marsh was interpreted and extended in Amalgamated Food Employees Local 590 v. Logan Valley Plaza, Inc., ${ }^{67}$ which prohibited a privately owned shopping center from using the state's trespass laws to abridge the first amendment rights of union picketers. The Court cited Marsh for the proposition that "under some circumstances property that is privately owned may, at least for First Amendment purposes, be treated as though it were publicly held." 68 The shopping center was found to be "the functional equivalent of the business district . . . involved in Marsh."69 Thus Logan Valley Plaza could not escape constitutional standards by claiming to be private property.

Applying this analysis to education reveals that schools do fulfill a public function, and that their practices are thus brought under the aegis of state action. Schools, regardless of their public or private management, are thought to contribute decisively to the future economic, technological, civic and cultural well being of the community. What children learn in school sets the tone of social life for.future generations. In this respect schools are quite different from private clubs and other entities where rights of association are paramount because they lack the public function which justifies constitutional regulation.

Though there are no cases holding that private schools serve a public function, Judge Skelly Wright expressed such a view in dictum in Guillory v. Administrators of Tulane University: ${ }^{70}$

64321 U.S. at 660.

65326 U.S. 501 (1946).

${ }^{66} I d$. at 506.

67391 U.S. 308 (1968).

${ }^{68}$ Id. at 316.

${ }^{69} \mathrm{Id}$. at 318 .

${ }^{70} 203$ F. Supp. 855,859 (E.D. La.), vacated on other grounds, 207 F. Supp. 554 (E.D. La.), aff'd, 306 F.2d 489 (5th Cir. 1962). 
Clearly, the administrators of a private college are performing a public function. They do the work of the state, often in place of the state. Does it not follow that they stand in the state's shoes? And, if so, are they not then agents of the state, subject to the constitutional restraints on governmental action, to the same extent as private persons who govern a company town ... or control a political party ... or run a city street car and bus service ... or operate a train terminal ... .

Reason and authority strongly suggest that the Constitution never sanctions racial discrimination in our schools and colleges, no matter how "private" they claim to be.

\section{Conclusion}

Traditionally, private racial discrimination has been considered a form of freedom of association and, therefore, immune from constitutional attack. However, under section two of the thirteenth amendment, Congress has limited the right of individuals to discriminate. Section 1982 of title 42 was interpreted by the Supreme Court in Jones v. Alfred H. Mayer Co. to be such a limitation on private action and, by analogy, section 1981 has been similarly applied.

Gonzales v. Fairfax-Brewster School, Inc. exemplifies the broad interpretation that the courts have given these sections in the wake of Jones; it also indicates the dangers to the right of privacy and the freedom of association which may follow too broad an application of the Jones rationale. Section 1981, however, can be applied to private discrimination without infringing upon associational interests if it is read as a prohibition of discrimination in contractual relationships of a secondary rather than a primary nature. Thus, in secondary relationships, no one could refuse to contract for reasons unrelated to the contract itself. In primary relationships, discrimination would be allowed under section 1981 , and only if there were state action violating the fourteenth amendment would such discrimination be barred.

This mode of analysis, which is consistent with the Court's decisions in Jones and Moose Lodge, would afford the appellate court in Gonzales two alternative grounds for affirming the district court's decision. The court's affirmation could be based on a finding, after a full consideration of the ties involved, that private schools are an example of a secondary relationship, or a finding that private schools perform a public function and therefore that their operation constitutes state action. A decision resting on either of these grounds is preferable to an unqualified 
application of the Jones rationale, for although it is unlikely that Jones will be overruled, it would be a dangerous trend if the expansion of its principles, already underway, were allowed to continue. 